chiefly related to its density and temperature. Now we know much respecting its rigidity.

With the object of increasing our knowledge of teleseismic disturbances, in 1896 the British Association, with the assistance of the British Government, communicated with many foreign States and Colonies suggesting that they should establish a certain type of seismograph. The result has been that the British Association now enjoys the cooperation of fifty-nine similarly equipped stations which are fairly evenly distributed over the world. The general outcome from this and the work carried out in Japan is that nearly every civilised country in the world has had its attention directed to this new departure in geophysics and has established seismographs.

In the last-mentioned country observers are to be found in most towns, and many instruments have been installed to record macroseisms and teleseisms. The annual outlay for earthquake work in that country is about 5oool. Russia, for the support of a system extending over its vast territories, expends a similar amount. Italy, which is the oldest country for recording earthquake phenomena, is covered with stations. Austria, France, Switzerland, Chile, the United States of America, the Balkan States and the small States of Centra! America each have their organised systems, while in Germany we find the headquarters of the International Seismological Association. This is supported by yearly contributions of about $1600 l$. from twenty-two countries. The headquarters of this body is in Strassburg, but it also controls stations in Beirut and Reykjavik. In Great Britain teleseisms are now recorded in thirteen different places. Three of these stations are owned by private persons, but the one in the Isle of Wight is largely supported by grants from the Royal Society, the British Association and Mr. M. H. Gray. The remaining nine are attached to existing observatories or other institutions.

J. Milne.

\section{THE PROBLEM OF TUBERCULOSIS.}

THE final report of the Departmental Committee on Tuberculosis was recently published. Since the interim report of r9i 2 (April) was issued the committee has been engaged in devising methods for dealing with the general problem of tuberculosis as it affects the community. This introduces at once the difficulty as to the policy to be followed with those cases occurring among the non-assured under the National Insurance Act. The funds for this purpose are now promised by the Government up to one half of the estimated cost, and whilst giving the ratepayers control of the local administration the funds mentioned are to be drawn from national sources.

Dr. Newsholme has shown how largely the improvement recorded in respect of this disease is really due, not so much to successful treatment, but more to the segregation of the advanced cases in special institutions, chinf among these being those wards of the Poor Law infirmaries set apart as sanatoria. But the law has till now left (and still leaves) the patient the right to "claim his discharge" when he pleases, and this is frequently exercised to his own detriment; but the committee now realises that, in addition, he is a source of danger to others in his environment. On this ground it is proposed to withdraw this liberty from the class of infective "ins and outs." It is a noteworthy point that the tuberculosis of children is now accepted by the committee as mainly of bovine origin.

The outstanding feature of the report is that of the provision for research, and its recognition in a fuller sense than has yet found its way to the statute book. The committee computes that an income for this purpose will accrue under the Insurance Act of about 57,0ool. a year, and it proposes the establishment of various grades of research workers, to include the appointment of full-time men, who shall entirely devote themselves to research "at an adequate salary," with a subsequent pension.

The outline of a detailed scheme is given which includes the use of existing agencies, but contemplates also the formation of a central bureau with an expert secretary director at the head. This is primarily designed for the reduction of statistics to comparable form, and may comprise a research institution as well.

In view of the scattered distribution of the workers some such arrangement is clearly necessary; and, further, the committee indicates the need, in its opinion, of keeping the workers in touch with the work done abroad.

The creation of scholarships is recommended, but a department of foreign inquiry, either by scholarship or commission, would enhance the knowledge of the whole body, and prove a constant stimulus to the highest effort.

A point of considerable importance is raised by the reference to laboratory facilities. "Access" to these by various local centres of work must always give way in effectiveness to work done by small equipments for diagnosis at these centres. The Commissioners consider that not merely tuberculosis, but any disease from which the assured may suffer may come under similar review.

On taking the figures from the rgog census report, tuberculosis claims 10.5 per cent. of all causes of mortality, and that of the "respiratory" group following-pneumonia and bronchitis-it will be noted that thus combined this figure exceeds the former. It must not be forgotten, however, that the latter includes cases of nondiagnosed tubercle, and others the essential feature of which is old age.

Tuberculosis, therefore, would claim the fullest, if not the sole, attention at first. This is confirmed by the figures just to hand of the results of the first year's working of the compulsory notification of infective diseases, including tubercle. Tuberculosis heads the list with $110,55^{\mathrm{I}}$ cases, which amount to $3^{\circ} \mathrm{c} 6$ per 1000

$$
\text { NO. 2269, VЭI. gI] }
$$


population. The next return is scarlet fever, $2^{*} 98$ per Iooo. This takes no account of the difference in mortality or disability entailed by these two diseases, and if allowed for would greatly raise the former.

The committee is to be congratulated upon an earnest attempt to deal constructively with a complex question. Its tendency throughout to ignore the medical department of the Local Government Board will doubtless be rectified later in the interests of unified public health administration.

\section{NOTES.}

The Secretary of State for the Colonies has appointed a Commission to study the nature and the relative frequency of the fevers occurring amongst the Europeans, natives, and others in West Africa, especially with regard to yellow fever and its minor manifestations. The members of the Commission are:-Sir James K. Fowler, K.C.V.O. (chairman), Major Sir Ronald Ross, K.C.B., F.R.S., Colonel Sir William Leishman, F.R.S., Prof. W. J. R. Simpson, C.M.G. Mr. A. Fiddian, of the Colonial Office, has been appointed secretary to the Commission, and $\mathrm{Mr}$. T. F. G. Mayer assistant secretary. In the absence of special reasons, the members of the Commission will not themselves proceed to West Africa, but local investigators will work under their direction at certain centres. As at present arranged, those centres will be Freetown in Sierra Leone and Sekondi and Accra on the Gold Coast. The investigation will be set on foot towards the end of April or early in May. Endeavours have been made to enlist the cooperation of all medical men practising in the British dependencies in West Africa, whether as Government medical officers or otherwise. The funds for this investigation will be provided by the West African dependencies.

M. Jules DE PAyer has furnished the Paris correspondent of The Pall Mall Gazette with particulars of his projected arctic expedition, which is intended to leave France in the summer. With the support of the Government and various societies, he will follow his father, the distinguished explorer, in making for Franz Josef Land. One of his objects is to locate the margin of the polar basin to the north-east of that archipelago, an investigation which, if successfully carried out, will provide data for an estimate of the relative areas of the basin and the continental shelf in that quarter of the arctic region. A scientific staff will accompany M. de Payer, with equipment for the prosecution of research in all the various departments which have become associated with polar work; among them the investigation of the upper atmosphere by means of kites is specially indicated. The party will be provided for a sojourn of one year or longer in the north, its ship returning in the meantime. It is to be provided with two aëroplanes, the utility of which as instruments in polar research will be observed with interest: a visit to the pole itself is mentioned as a possibility, but does not appear as a prime object of the expedition. Wireless telegraphy will be installed at the headquarters.

$$
\text { NO. 2269, VOL. 91] }
$$

AlL who had the pleasure of the acquaintarco of Mr. Carl Hagenbeck - whose death occurred at Hamburg on April I5-could not fail to recognise the indomitable will and dogged perseverance of the man, coupled as they were with a manner of unusual gentleness and kindliness. It was no doubt owing to this unusual combination that Hagenbeck was so signally successful in his trade, for by the former traits he carried out in the most thorough manner every venture upon which he embarked, while by the latter he attracted and tamed his captives in a manner peculiarly his own. Born in a suburb of Hamburg in I844, young Hagenbeck early acquired an interest in animals from his father, and eventually succeeded in securing the greater portion of the world's trade in wild beasts. In fact, if an animal was wanted you had but to tell Hagenbeck, and, unless war or other political obstacles barred the way, it was practically sure to come. But Hagenbeck's fame was largely based on his novel ideas with regard to the treatment of wild animals in confinement, more especially in the matter of an outdoor life for tropical species in Europe, and in the abolition of visible walls and bars, so that spectators might behold the captives in a state of comparative freedom. These ideas were embodied in the animal park at Stellingen. In I899 Hagenbeck published, under the title "Von Tieren und Menschen," an account of his life and experiences, an abbreviated English translation of which appeared during the same year.

THE South Metropolitan Gas Company has appointed Mr. J. S. G. Thomas as research physicist to undertake investigations for technical purposes.

THE death is announced, at fifty-two years of age, of Prof. A. C. Elliott, professor of engineering at the University College of South Wales and Monmouthshire, and president of the Institution of Locomotive Engineers.

Mr. A. R. Hinks, F.R.S., chief assistant at the Cambridge University Observatory, has been appointed Gresham professor of astronomy, London, in succession to the late Mr. S. A. Saunder.

Pror. L. J. Landouzy, dean of the Paris faculty of medicine, and known by his researches in connection with nervous diseases and tuberculosis, has been elected a member of the Paris Academy of Sciences, in succession to the late $\mathrm{M}$. Teisserenc de Bort.

ON Thursday last, April 17 , Mr. G. Hamel, accompanied by a passenger, accomplished a non-stop flight on a two-seater Blériot monoplane from Dover to Cologne, the direct distance being nearly 250 miles, in about four hours and a quarter.

Aт the ordinary scientific meeting of the Chemical Society, held on Thursday, April I7, the president, Prof. W. H. Perkin, F.R.S., announced that an extra meeting will be held in the rooms of the society on Thursday, May 22, at 8.30 p.m., when a lecture in honour of the memory of the late Prof. Jacobus Henricus van't Hoff, honorary and foreign member, will be delivered by Prof. James Walker, F.R.S., of Edinburgh. 